\title{
Site fidelity and movement of Chelonoidis carbonaria (Spix, 1824) (Testudinidae) in cocoa plantations in southeastern Brazil
}

\author{
Borini, JF. ${ }^{a *}$, Petrucci, BB. ${ }^{a}$, Krohling, $W^{a}{ }^{a}$, Rossi Júnior, JL. ${ }^{a}$, Santos, \\ MRD. ${ }^{a}$ and Ferreira Júnior, PD. ${ }^{a}$ \\ aPrograma de Pós-graduação em Ecologia de Ecossistemas, Universidade Vila Velha - UVV, \\ Rua Comissário José Dantas de Melo, 21, Boa Vista, CEP 29102-770, Vila Velha, ES, Brazil \\ *e-mail: jordanaborini@gmail.com
}

Received: July 16, 2012 - Accepted: July 31, 2013 - Distributed: November 302014

(With 1 figure)

\begin{abstract}
Red-footed Tortoises (Chelonoidis carbonaria Spix, 1824) raised as pets and voluntarily handed over to environmental officers by their owners or apprehended by officers represent a large contingent of animals that overfill triage centres in Brazil. There is no consensus on the fate of these animals, and their numbers continue growing. In this study, we evaluated the movement patterns of $C$. carbonaria originating from triage centres in areas of cocoa plantations and forest remnants to define their home range and dispersion. After 120 days of quarantine and acclimatisation, eight C. carbonaria adults were released and monitored via radio telemetry for 10 months. The radio transmitters of two individuals presented problems, and consequently, it was not possible to track these individuals. Five individuals remained in an area of 7.75 ha 10 months after release, avoiding contact with humans after the first three months. The greatest problems were the proximity of individuals to inhabited areas in the first three months after release, the death of two individuals, and the escape of one individual. After the experiment, the animals were sent back to the triage centre. Our results suggest that a proportion of the animals in the triage centres are able to survive in natural conditions. Considering their survival and fidelity to the release site, the translocation of animals described herein should be considered partially successful. However, if this measure is adopted, it must be preceded by studies of the animals' origins and by a rigorous genetic, sanitary and behavioural analysis of each individual.
\end{abstract}

Keywords: conservation, post-release monitoring, Red-footed Tortoise, telemetry.

\section{Estabelecimento e movimentação de Chelonoidis carbonaria (Spix, 1824) (Testudinidae) em áreas de plantação de cacau no sudeste do Brasil}

\begin{abstract}
Resumo
Jabutis criados como animais de estimação entregues voluntariamente por seus donos ou apreendidos pelos agentes ambientais formam um grande contingente de animais que lotam os centros de triagem nas diversas regiões do Brasil. Não existe um consenso sobre o destino destes animais e os seus números continuam a crescer. Neste estudo avaliamos os deslocamentos de Chelonoidis carbonaria oriundos de centros de triagem em áreas de plantio de cacau e de remanescentes florestais buscando levantar a área de vida e a dispersão dos indivíduos. Após um período de quarentena e aclimatação de 120 dias 10 indivíduos adultos de C. carbonaria foram soltos e monitorados por radiotelemetria durante 10 meses. Os radiotransmissores de dois indivíduos apresentaram problemas não sendo possível acompanha-los. Cinco indivíduos permaneceram na área após 10 meses de soltura evitando, após os três meses iniciais, o contato com os humanos e vivendo em uma área de até 7,75 ha. Os principais problemas verificados foram a aproximação dos indivíduos das áreas habitadas nos três primeiros meses após a soltura, a morte de dois indivíduos e a dispersão de outro. Ao final do experimento os animais foram devolvidos ao centro de triagem de origem. Nossos resultados sugerem que uma parcela dos animais dos centros de triagem apresenta condições sobreviver em condições naturais. Considerando a sobrevivência e a fidelidade à área de soltura uma possível translocação poderia apresentar um sucesso parcial. Esta medida, entretanto, caso seja adotada, deve ser precedida de estudos sobre a origem dos animais e de uma rigorosa análise genética, sanitária e comportamental de cada indivíduo.
\end{abstract}

Palavras-chave: conservação, monitoramento, jabuti-piranga, Testudines, telemetria. 


\section{Introduction}

Projects aimed at the management and conservation of endangered species frequently use translocation as a tool for the revival or establishment of a self-sustaining population. Translocation is a broad concept that involves reintroduction, supplementation, reallocation or introduction (Griffith et al., 1989; Dodd and Seigel, 1991; Pedrono and Sarovy, 2000). A successful translocation implies that the new individuals become part of the resident population and that they subsist without human intervention (Waples and Stagoll, 1997; Ashton and Burke, 2007; Soorae, 2010). The IUCN (1998) has raised several questions concerning the reintroduction of species, especially with regard to genetic pollution and introduction of diseases into the native population (Cunningham, 1996; Ashton and Burke, 2007). When the translocation involves confiscated animals or animals from captivity, the restrictions are even greater with regard to the transmission of disease and parasites and the low survival rate of these individuals in the natural environment (IUCN, 2002; Wimberger et al., 2010). In many cases, the euthanasia of captive animals is recommended; however, many institutions are reluctant to perform this procedure due to ethical questions and the anti-educational aspect inherent in this procedure. One alternative for animals that were confiscated or those that were voluntarily handed over is donation to wildlife sanctuaries that contain large, preserved areas with continuous management and intensive protection (Soorae, 2010).

If translocation is decided upon and all the genetic (IUCN, 1998), sanitary (Jacobson et al., 1999; Woodford, 2000; Martel et al., 2009) and legal (IBAMA, 2008) restrictions are resolved, it is essential that the behaviour of the animals has not been altered in captivity and that they can survive in the natural environment without compromising the resident population. After the release, translocated individuals and the resident population need to be monitored to evaluate the effectiveness of translocation (Cunningham, 1996). Several post-release monitoring and medium-term studies have focused on the tortoises Gopherus polyphemus (Daudin, 1802) (Lohoefener and Lohmeier, 1986; Ashton and Burke, 2007), Gopherus agassizii (Cooper, 1863) (Ashton and Burke, 2007; Field et al., 2007), Astrochelys yniphora (Vaillant, 1885) (Pedrono and Sarovy, 2000), Testudo hermanni (Gmelin, 1789) (Bertolero et al., 2007), Psammobates pardalis (Bell, 1828) (Wimberger et al., 2009) and the box turtle Terrapene carolina (Linnaeus, 1758) (Cook, 2004; Hester et al., 2008). In Brazil, one study on the Red-footed Tortoise (Chelonoidis carbonaria) monitored the release of 86 individuals for only 10 days (Salvador et al., 2009). Longer-term monitoring is necessary to determine whether translocation is an efficient method of management and conservation of $C$. carbonaria. The aim of this study was to evaluate whether individuals kept in captivity for a long time are able to survive in natural conditions. Accordingly, we monitored movement and habitat use after release. We assumed that some of the animals that spent a long period in captivity would be able to establish a living area and avoid contact with humans.

\section{Methodology}

Chelonoidis carbonaria were translocated into a 363 ha farm in Linhares, which is located in northern Espírito Santo, Brazil (19²8'S, 5953'W). Of the 363 ha, 165 ha were utilised for cocoa cultivation and the remaining 198 ha were utilised for pasture and eucalyptus cultivation. In this area, there are seven occupied houses, two houses in ruins, farmyards and cocoa warehouses. Roads and trails connect the facilities and separate the cocoa plantations. These roads are narrow $( \pm 7 \mathrm{~m})$, precarious, sporadically maintained and seldom used by vehicles. The farm is located in the deltaic plains of the Doce River, which was originally covered by the Atlantic Forest (specifically, dense ombrophilous forest). The alluvial plain of the Doce River consists of 17,000 ha of forests in the cabruca system (an agroforestry system in which cocoa trees [Theobroma cacao L.] grow under a canopy that consists of a mix of native primary or secondary trees and productive fruit trees). Only a fraction of the trees in the native forest are conserved; the understory is replaced by cocoa trees (Sambuichi, 2002). The average temperature is $24 \mathrm{C} /$ year, and the rainfall is $1,200 \mathrm{~mm} /$ year. The cabruca offers the largest continuous forested area outside the reserves in the Doce River plain and is the most appropriate area for the experiment owing to the partially preserved dense ombrophilous forest conditions, the ease of monitoring (sparse sub forest) and the low human population density in the cocoa farms. Despite the absence of official records, anecdotal information and a previous sighting by one member of our group in the 1980s suggest that C. carbonaria naturally occur in this area.

At the Centre for Reintroduction of Wild Animals (Centro de Reintrodução de Animais Silvestres [CEREIAS]), eight adult $C$. carbonaria (four females and four males) were chosen for the experiment. All individuals had curved carapace lengths longer than $28 \mathrm{~cm}$, indicating that they were adults (Jerozolimski, 2005). Males were heavier $(5.6 \pm 1.5 \mathrm{~kg})$ and had longer curved carapace lengths $(41.5 \pm 2.3 \mathrm{~cm})$ than females $(4.3 \pm 0.4 \mathrm{~kg}$ and $36.8 \pm 2.6 \mathrm{~cm})$. The CEREIAS individuals were obtained via confiscations or donations in the state of Espírito Santo, and there were no records of the geographical origins of these animals. Only healthy-looking individuals of similar size and sexual maturity were chosen for the experiment. The animals went through quarantine at the Veterinary Hospital of Vila Velha University. Each tortoise was housed in an individual pen for 60 days and fed once a day with fruits and greenery. The individuals were subjected to parasitological examinations, bacteriological oropharyngeal swabs, complete blood tests and plasma biochemical analysis. Females underwent an additional X-ray examination to verify the presence of eggs. One of the females nested during the quarantine period. All the hematological and biochemical examinations presented values that were within the normal reference ranges according to Cubas and Baptistotte (2006). The animals chosen for release were housed within an enclosure (approximately $100 \mathrm{~m}^{2}$ ) 
on the farm for acclimation and quarantine for 60 days, for a total of 120 days under observation. During this period, the animals received food found on the property. After the death of two individuals (one male and one female) in May 2010, two additional C. carbonaria (one male and one female) were used as replacements after undergoing the same procedures and the quarantine; the replacement animals were monitored only with radio transmitters.

The movement patterns of the translocated tortoises were studied using radio telemetry and spools of thread (Coats Corrente Ltda., São Paulo, SP, Brazil) attached to the carapace. For the radio telemetry, a radio receiver (Yaesu Inc., Cypress, CA, USA) with a three-element Yagi-Uda antenna (4 db) and radio transmitters (AVM Instrument Company Ltd., Colfax, CA, USA) were used. The spools of thread and the radio transmitters were fixed with fast-drying epoxy putty on the posterior region of the carapace. Initially, telemetry and spooling monitoring were performed fortnightly and monthly beginning in April. The individuals were released in the cabruca area of the study site on March 13, 2010, and the monitoring period lasted until December 20, 2010. After this time period, all the individuals found were returned to CEREIAS. Displacement was recorded through the uncoiling of the thread from the spool, and the path and location of the individuals were recorded with a GPS (Garmin Etrex Legend HCX). The area utilised by the individuals was calculated via the minimum convex polygon method using both telemetry and spooling data with ArcGis software (version 9.3). Comparisons between male and female living areas were made using the Student's t test.

\section{Results}

After their release on March 13, 2010, the individuals travelled short distances. They changed the direction of their movement abruptly without presenting a preferential direction. In the first two weeks after release, the individuals started to move through the road that intersects the cabruca without leaving the cocoa plantation. Some individuals abandoned the road and headed between the vegetation in rectilinear and unidirectional movements. After these movements, they returned to the road and frequently walked back and forth across it. All C. carbonaria used an area of 30.65 ha (Figure 1). The displacement pattern, distance covered, and area utilised varied among the individuals and throughout the monitoring period. Males had a larger activity range $(7.2 \pm 0.56 \mathrm{ha})$ than females $(3.7 \pm 0.77 \mathrm{ha}$; $t=6.6 ; P<0.001)$.

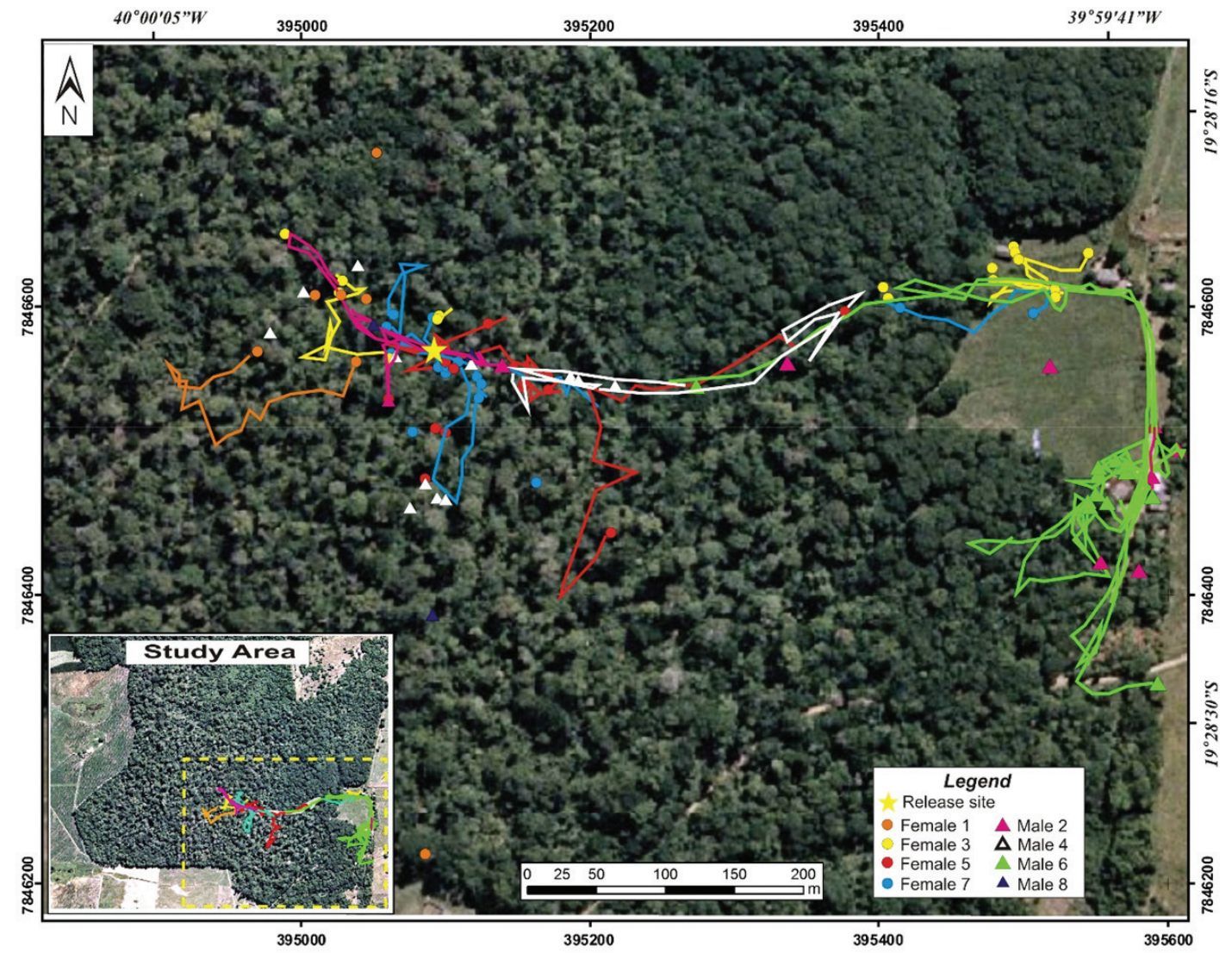

Figure 1. Displacement of Chelonoidis carbonaria during the monitored period. The dots indicate where the individuals were found and the lines the movement according to the spooling. 
In the first three months after their release, several individuals were often found around the houses and farmyards. The road that intersects the cabruca was used by all individuals, which generally (although not always) avoided the open areas of the pasture during their movements. Over the 10 months of monitoring, five individuals (two females and three males) remained in the vicinity of the release area approximately $600 \mathrm{~m}$ from the release point (Table 1). Two individuals were found dead in July 2010 (F7 female and M4 male), and the radio transmitter became detached from two other individuals (one female and one male). We assumed that one female dispersed in May because its radio signal was lost, and it was moving continuously from the release point. The last transmission from this female was at $1800 \mathrm{~m}$ from the release point. Eighteen months after release, in a random visit to the area (monitoring ended ten months after release), three individuals (one male and two females) were found in good, healthy condition on the edge of a small drainage that intersects a pasture approximately $500 \mathrm{~m}$ away from the release site.

One dead female (F7) was found in July 2010 on the road inside the cabruca. It was not possible to determine the cause of death; however, the unchanged aspect of the carapace eliminated the possibility of death by predation. Traces of mud on the shell of this female indicated that it remained for a relatively long period of time in a puddle. A male (M4) was also found dead in July, and the post mortem examination result was incompatible with predation. Another female (F3) spent one month within the cabruca before moving from the edge of the cabruca to the ruins of a house, using it as a shelter for approximately 15 days. After this period, it moved through the pasture toward an inhabited house and wandered around it unbothered by the residents of the house or their pets. This female remained in the vicinity of the inhabited house, where it often received food from other house residents, until December, when it returned to the cabruca and no longer interacted with people. Another male (M6) exhibited peculiar behaviour. After one week in the cabruca, it began surrounding a house, continuing this behaviour until June 2010. Its movement around the house was marked by constant back and forth walks. After June 2010, this male went into the cabruca, staying in a small area until December 2010.

\section{Discussion}

The patterns of movement and the establishment of a home range are important indicators of turtles' response to translocation (Hester et al., 2008). Translocated tortoises initially present erratic and irregular movement typical of disorientation in a non-familiar environment; these erratic movements are followed by unidirectional movements that are characteristic of the search for a new environment (Posey, 1979; Caldwell and Nams, 2006; Hester et al., 2008; Saumure et al., 2009). This pattern was verified in C. carbonaria: On the first days after release, movements were random and frequently in arcs. However, rectilinear movements could be observed in the first week after release, and displacement movements were performed mainly on the road that intersects the cabruca or its surroundings.

Table 1. Pre-release Chelonoidis carbonaria measures, monitoring time and individual status on the end of the study or until their demise. The home range was calculated using telemetry and spooling data. CCL (curved carapace length); plastron length (PL).

\begin{tabular}{|c|c|c|c|c|c|c|c|c|}
\hline \multicolumn{9}{|c|}{ Monitoring end } \\
\hline Sex & $\begin{array}{l}\text { CCL } \\
\text { (cm) }\end{array}$ & $\begin{array}{c}\text { PL } \\
\text { (cm) }\end{array}$ & $\begin{array}{l}\text { Weight } \\
\text { (kg) }\end{array}$ & Release & Telemetry & Spooling & $\begin{array}{c}\text { Home } \\
\text { range } \\
\text { (ha) }\end{array}$ & Status \\
\hline M2 & 39.5 & 24.7 & 3.75 & 13 March & 4 May & 26 April & 8.18 & $\begin{array}{c}\text { Unknown } \\
\text { (transmissor lost) }\end{array}$ \\
\hline M4 & 43.9 & 30 & 7.02 & 13 March & 12 July & 12 July & 6.65 & Died in July \\
\hline M6 & 41.3 & 26.3 & 5.2 & 13 March & 20 December & 12 July & 7.76 & $\begin{array}{c}\text { Live in December } \\
2010\end{array}$ \\
\hline M8 & 42.1 & 26.5 & 6.58 & 13 March & 20 December & 12 July & 7.35 & $\begin{array}{c}\text { Live in December } \\
2010\end{array}$ \\
\hline M10 & 50.4 & 40.6 & 8.12 & 4 October & 20 December & & & $\begin{array}{c}\text { Live in September } \\
2011\end{array}$ \\
\hline F1 & 40.4 & 24 & 4.6 & 13 March & 21 May & 26 April & 4.01 & $\begin{array}{l}\text { Unknown } \\
\text { (dispersed?) }\end{array}$ \\
\hline F3 & 39.2 & 22.3 & 4.56 & 13 March & 20 December & 12 July & 2.75 & $\begin{array}{c}\text { Live in September } \\
2011\end{array}$ \\
\hline F5 & 37.5 & 23.1 & 4.38 & 13 March & 12 July & & 3.57 & $\begin{array}{c}\text { Unknown } \\
\text { (transmissor lost) }\end{array}$ \\
\hline F7 & 34.2 & 23.2 & 3.68 & 13 March & 12 July & 12 July & 4.58 & Died in July \\
\hline F9 & 28.5 & 20.4 & 3.71 & 4 October & 20 December & & & $\begin{array}{c}\text { Live in September } \\
2011\end{array}$ \\
\hline
\end{tabular}


Changes in the movement pattern of translocated turtles after long periods of captivity indicate the acquisition of familiarity with the area and exploration of its resources (Hester et al., 2008; Saumure et al., 2009). This shift in movement was also verified with $C$. carbonaria, suggesting the beginning of adaptation to the new environment. After the first two weeks of freedom, the landscape change was not a barrier to the movement of C. carbonaria, and some individuals began to circle between the houses and pastures without being restricted to the cabruca area.

The lack of fidelity to the release area, the utilisation of large areas and long-distance movements, and the dispersion of individuals after translocation are features that are apparently common to several species of tortoises and are among the biggest problems inherent in this management strategy (Field et al., 2007; Hester et al., 2008; Germano and Bishop, 2009). Dispersion and low fidelity to the release site were verified in one C. carbonaria individual that was tracked for only two months and subsequently drifted away from the area. A low level of dispersion has been verified in native individuals, which is a trait that is apparently inherent to the species; thus, this fact must be taken into account in translocation projects (Eubanks et al., 2003; Jerozolimski, 2005). The increased movement of males compared with females could be a result of reproductive behaviour. Chelonoidis carbonaria are more active at earlier stages and move more than females, increasing the chance of finding a mate (Moskovits and Kiester, 1987).

The $C$. carbonaria that were still being monitored became more loyal to the area after June. However, a home range for $C$. carbonaria could not be established during the monitoring period and was only established in the second year for Astrochelys yniphora (Pedrono and Sarovy, 2000), Gopherus polyphemus (Tuberville et al., 2005) and Gopherus agassizii (Field et al., 2007) and after two years for Terrapene carolina (Belzer, 2002; Cook, 2004). The behaviour of C. carbonaria and its area use varied among individuals in this study, which was also noted previously among free individuals (Moskovits and Kiester, 1987; Jerozolimski, 2005; Strong and Fragoso, 2006). The reduction in dispersal and distance covered may be related to greater familiarity with the location (Field et al., 2007). The size of the area used by the translocated $C$. carbonaria is within the limits presented in other studies for native populations from Ilha de Maracá in the state of Roraima (0.6-117.5 ha; Moskovits and Kiester, 1987) and in the Xingu Indigenous Park in the state of Mato Grosso (2.5-167.7 ha; Jerozolimski, 2005), indicating that despite the ecological and environmental differences, the resources from cabruca are sufficient to maintain the tortoises.

The use of roads and the proximity to the houses in the first three months after release were the main problems for the $C$. carbonaria used in this experiment. The roads are often used as individual paths due to the ease of displacement and higher temperatures; however, they also represent a problem. Roads facilitate the dispersion and departure of individuals from preserved areas, increase exposure to predators, increase the likelihood of accidents and facilitate the collection of animals (Wimberger et al., 2009). When choosing release areas, roads should be carefully evaluated because they can divide the preserved areas, altering the natural displacement in the forested areas and serving as a route for the dispersion of individuals.

The origin of the individuals used in this study was not clear, although they were obtained from apprehensions and voluntary donations and had usually been kept as pets. Long periods of time in the company of humans, the food supply, and the capacity for learning through observation (Wilkinson et al., 2010) suggest imprinting in these individuals. Despite the initial permanence of these individuals in the cabruca, they approached the houses and interacted with the residents. In a project intended to translocate the individuals, these situations would expose the C. carbonaria to collection and other accidents (Trombulak and Frissell, 2000). This fact demonstrates the importance of involvement of the local population in the rehabilitation of animals (Soorae, 2010). In this study, after three months in the vicinity of the houses, the individuals dispersed. Acclimatisation to the vicinity of houses was not adequate, and in this case, it is recommended that acclimatisation be performed in fenced spaces located in the middle of an area of at least 30 ha. This value considers the area that was utilised over ten months by all the individuals that were monitored in this study.

Considering the survivorship and fidelity to the release site, the translocation of C. carbonaria may be feasible for individuals being kept in the triage centres, as previously proposed by Salvador et al. (2009). Wimberger et al. (2009) stated that the release of Psammobates pardalis was partially successful when five of 17 tortoises survived at 13 months after release. In our study, five of the eight C. carbonaria released remained near the release point after 10 months, and after 18 months, three were found in good health. The difficulties of the translocation of C. carbonaria were related to the proximity to buildings in the first three months after release, dispersion of some individuals, and deaths. The survival rate of tortoises in the first year of release varies according to the species in question and depends on the conditions and moment of release, and it is important to keep in mind that the mortality rate is higher after the first year of translocation (Pedrono and Sarovy, 2000; Field et al., 2007; Wimberger et al., 2009; Salvador et al., 2009).

The constant displacement, climatic variations, and the search for food are factors that may cause immunosuppression, allowing for the development of diseases. Wimberger et al. (2009) reported that $52 \%$ of translocated $P$. pardalis die in the first months of release from a combination of diseases, dehydration, and malnutrition. Respiratory diseases are also one of the main causes of death in translocated Terrapene carolina (Cook, 2004). Despite the examinations, the quarantine period and the favourable clinical results obtained in this study, at least one C. carbonaria died due to septicemic disease, which may have occurred as a result of an infection that developed after release. Martel et al. 
(2009) reported a relatively high prevalence of the herpes virus in captive tortoises. It is very likely that this male died due to a combination of factors, among which the herpes virus may be involved, and the infection may have been secondary to the herpes lesions.

If translocation is decided upon after a cost-benefit analysis (IUCN, 1998, 2002; IBAMA, 2008), the release of the animals must be preceded by judicious selection of individuals, rigorous sanitary and behavioral evaluation during quarantine (Woodford 2000; Tuberville et al., 2005), and a careful choice of release site. This initiative must involve the local community, and continuous monitoring of the individuals is essential for evaluating the effectiveness of this management tool.

\section{Acknowledgements}

We would like to thank Liliane Batista de Deus and Clarkson Diniz for permission to perform the experiments in the Fazenda Esperança, Orozino Silva and Fabrício Ferreira for aid in locating and monitoring the tortoises, and Vila Velha University for providing the tools needed for the clinical examinations and the facilities used during the quarantine. All the procedures were authorised by the Instituto Brasileiro de Meio Ambiente e Recursos Naturais Renováveis (064/11 - NUFAU/IBAMA/ES 02009.001702/2009-01) and approved by the Ethics, Bioethics and Animal Welfare Committee (Comitê de Ética, Bioética e Bem Estar Animal) of Vila Velha University.

\section{References}

ASHTON, KG. and BURKE, RL., 2007. Long-term retention of a relocated population of gopher tortoises. The Journal of Wildlife Management, vol. 71, no. 3, p. 783-787. http://dx.doi. org/10.2193/2005-583.

BELZER, B., 2002. A nine year study of eastern box turtle courtship with implications for reproductive success and conservation in a translocated population. Turtle and Tortoise Newsletter, vol. 6, no. 1, p. 17-26.

BERTOLERO, A., ORO, D. and BESNARD, A., 2007. Assessing the efficacy of reintroduction programmes by modelling adult survival: the example of Hermann's tortoise. Animal Conservation, vol. 10, no. 3, p. 360-368. http://dx.doi.org/10.1111/j.14691795.2007.00121.x

CALDWELL, IR. and NAMS, VO., 2006. A compass without a map: tortuosity and orientation of eastern painted turtles (Chrysemys picta picta) released in unfamiliar territory. Canadian Journal of Zoology, vol. 84, no. 8, p. 1129-1137. http://dx.doi. org/10.1139/z06-102.

COOK, RP., 2004. Dispersal, home range establishment, survival, and reproduction of translocated eastern box turtles, Terrapene c. carolina. Applied Herpetology, vol. 1, no. 3, p. 197-228. http:// dx.doi.org/10.1163/157075403323012197.

CUBAS, PH. and BAPTISTOTTE, C., 2006. Chelonia (Tartaruga, Cágado, Jabuti). In CUBAS, ZS., SILVA, JCR. and CATÃODIAS, JL. Tratado de animais selvagens: medicina veterinária. São Paulo: Roca. p. 86-119.
CUNNINGHAM, AA., 1996. Disease risks of wildlife translocations. Conservation Biology, vol. 10, no. 2, p. 349-353. http://dx.doi. org/10.1046/j.1523-1739.1996.10020349.x.

DODD, CK. and SEIGEL, RA., 1991. Relocation, repatriation, and translocation of amphibians and reptiles: are they conservation strategies that work? Herpetologica, vol. 47, no. 3, p. 336-350.

EUBANKS, JO., MICHENER, WK. and GUYER, C., 2003. Patterns of movement and burrow use in a population of gopher tortoises (Gopherus polyphemus). Herpetologica, vol. 59, no. 3, p. 311-321. http://dx.doi.org/10.1655/01-105.1.

FIELD, KJ., TRACY, CR., MEDICA, PA., MARLOW, RW. and CORN, PS., 2007. Return to the wild: translocation as a tool in conservation of the desert tortoise (Gopherus agassizii). Biological Conservation, vol. 136, no. 2, p. 232-245. http://dx.doi. org/10.1016/j.biocon.2006.11.022.

GERMANO, JM. and BISHOP, PJ., 2009. Suitability of amphibians and reptiles for translocation. Conservation Biology: the journal of the Society for Conservation Biology, vol. 23, no. 1, p. 7-15. http:// dx.doi.org/10.1111/j.1523-1739.2008.01123.x. PMid:19143783

GRIFFITH, B., SCOTT, JM., CARPENTER, JW. and REED, C., 1989. Translocation as a species conservation tool: status and strategy. Science, vol. 245 , no. 4917 , p. 477-480. http://dx.doi. org/10.1126/science.245.4917.477. PMid:17750257

HESTER, JM., PRICE, SJ. and DORCAS, ME., 2008. Effects of relocation on movements and home ranges of eastern box turtles. The Journal of Wildlife Management, vol. 72, no. 3, p. 772-777. http://dx.doi.org/10.2193/2007-049.

Instituto Brasileiro do Meio Ambiente e dos Recursos Naturais Renováveis - IBAMA, 2008. Instrução Normativa no 179, de 25 de junho de 2008. Define as diretrizes e procedimentos para destinação dos animais silvestres apreendidos, resgatados ou entregues espontaneamente às autoridades competentes. Brasília: IBAMA. Available from: $<$ http://www.icmbio.gov.br/ran/images/ stories/legislacao/IN_IBAMA_179_destina\%C3\%A7\%C3\%A3o. pdf $>$.

International Union for Conservation of Nature and Natural Resources - IUCN, 1998. IUCN Guidelines for Re-introductions. Prepared by the IUCN/SSC Re-introduction Specialist Group. Gland/Cambridge: IUCN. $10 \mathrm{p}$.

International Union for Conservation of Nature and Natural Resources - IUCN, 2002. IUCN Guidelines for the placement of confiscated animals. Gland/Abu Dhabi: IUCN/ERWDA. 24 p.

JACOBSON, ER., BEHRER, JL. and JARCHOW, JL., 1999. Health assessment of Chelonians and release into the wild. In FOWLER, ME. and MILLER, ER. Zoo and wild animal medicine: current therapy. Philadelphia: W.B. Saunders. p. 232-242.

JEROZOLIMSKI, A., 2005. Ecologia de populações silvestres dos jabutis Geochelone denticulata e G. carbonaria (Cryptodira: Testudinidae) no território da aldeia A'Ukre, TI Kayapó, sul do Pará. São Paulo: Instituto de Biociências, Universidade de São Paulo. 242 p. PhD Thesis in Ecology.

LOHOEFENER, R. and LOHMEIER, L., 1986. Experiments with gopher tortoise (Gopherus polyphemus) relocation in southern Mississippi. Herpetological Review, vol. 17, no. 1, p. 37-40.

MARTEL, A., BLAHAK, S., VISSENAEKENS, H. and PASMANS, F., 2009. Reintroduction of clinically healthy tortoises: the herpesvirus Trojan horse. Journal of Wildlife Diseases, vol. 45, no. 1, p. 218-220. http://dx.doi.org/10.7589/0090-3558-45.1.218. PMid:19204353 
MOSKOVITS, DK. and KIESTER, AR., 1987. Activity levels and ranging behaviour of the two amazonian tortoises, Geochelone carbonaria and Geochelone denticulata, in North-Western Brazil. Functional Ecology, vol. 1, no. 3, p. 203-214. http://dx.doi. org/10.2307/2389422.

PEDRONO, M. and SAROVY, A., 2000. Trial release of the world's rarest tortoise Geochelone yniphora in Madagascar. Biological Conservation, vol. 95, no. 3, p. 333-342. http://dx.doi. org/10.1016/S0006-3207(00)00023-9.

POSEY, MH., 1979. A study of the homing instinct in Terrapene c. carolina in Maryland. Bulletin of the Maryland Herpetological Society, vol. 15, no. 4, p. 139-140.

SALVADOR, GDN., MACHADO, TO., LO, VK., ALMEIDA, OB. and LADEIA, RF., 2009. Repatriação e reintrodução de jabuti-piranga Chelonoidis carbonaria (Testudinidae) Tremedal/ BA. In Instituto Brasileiro do Meio Ambiente e dos Recursos Naturais Renováveis - IBAMA. Relatório de atividades das ASM - Áreas de soltura e monitoramento de animais silvestres organizado pelo departamento de comunicação do IBAMA-SP. São Paulo: IBAMA. p. 50-57. (Rélatório de Atividades das ASM).

SAMBUICHI, RHR., 2002. Fitossociologia e diversidade de espécies arbóreas em cabruca (Mata Atlântica raleada sobre plantação de cacau) na região sul da Bahia, Brasil. Acta Botanica Brasilica, vol. 16, no. 1, p. 89-101. http://dx.doi.org/10.1590/ S0102-33062002000100011.

SAUMURE, RA., HERMAN, TB. and TITMAN, RD., 2009. Effects of patch size and habitat structure on the movements of adult male Wood Turtles, Glyptemys insculpta. Herpetological Conservation and Biology, vol. 5, no. 3, p. 403-413.

SOORAE, PS. (Ed.), 2010. Global Re-introduction perspectives: additional case-studies from around the globe. Abu Dhabi: IUCN/ SSC Re-introduction Specialist Group. 352 p.

STRONG, JN. and FRAGOSO, JMV., 2006. Seed dispersal by Geochelone carbonaria and Geochelone denticulata in
Northwestern Brazil. Biotropica, vol. 38, no. 5, p. 683-686. http:// dx.doi.org/10.1111/j.1744-7429.2006.00185.x.

TROMBULAK, SC. and FRISSELL, CA., 2000. Review of ecological effects of roads on terrestrial and aquatic communities. Conservation Biology, vol. 14, no. 1, p. 18-30. http://dx.doi. org/10.1046/j.1523-1739.2000.99084.x.

TUBERVILLE, TD., CLARK, EE., BUHLMANN, KA. and GIBBONS, JW., 2005. Translocation as a conservation tool: site fidelity and movement of repatriated Gopher Tortoises (Gopherus polyphemus). Animal Conservation, vol. 8, no. 4, p. 349-358. http://dx.doi.org/10.1017/S1367943005002398.

WAPLES, KA. and STAGOLL, CS., 1997. Ethical issues in the release of animals from captivity. Bioscience, vol. 47, no. 2, p. 115-121. http://dx.doi.org/10.2307/1313022.

WILKINSON, A., KUENSTNER, K., MUELLER, J. and HUBER, L., 2010. Social learning in a non-social reptile (Geochelone carbonaria). Biology Letters, vol. 6, no. 5, p. 614-616. http:// dx.doi.org/10.1098/rsbl.2010.0092. PMid:20356886

WIMBERGER, K., ARMSTRONG, AJ. and DOWNS, CT., 2009. Can rehabilitated Leopard Tortoises, Stigmochelys pardalis, be successfully released into the wild? Chelonian Conservation and Biology, vol. 8, no. 2, p. 173-184. http://dx.doi.org/10.2744/ CCB-0773.1.

WIMBERGER, K., ARMSTRONG, AJ. and DOWNS, CT., 2010. Welfare release of Babcock's leopard tortoise, KwaZulu-Natal, South África. In SOORAE, PS. (Ed.). Global Re-introduction Perspectives: additional case-studies from around the globe. Abu Dhabi: IUCN/SSC Re-introduction Specialist Group. p. 102-112.

WOODFORD, MH. (Ed.), 2000. Quarantine and health screening protocols for wildlife prior to translocation and release into the wild. Glande: IUCN Species Survival Commission's Veterinary Specialist Group/Office International des Epizooties/Care for the Wild/European Association of Zoo and Wildlife Veterinarians. 87 p. 